\title{
The Dangers of Deficit Reduction
}

\author{
JOSEPH E. STIGLITZ
}

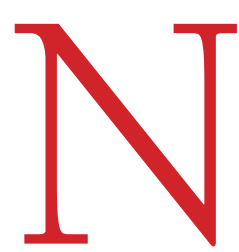

EW YORK-A wave of fiscal austerity is rushing over Europe and America. The magnitude of budget deficits-like the magnitude of the downturn-has taken many by surprise. But despite protests by yesterday's proponents of deregulation, who would like the government to remain passive, most economists believe that government spending has made a difference, helping to avert another Great Depression.

Most economists also agree that it is a mistake to look at only one side of a balance sheet

Joseph E. Stiglitz is University Professor at Columbia University and recipient of the 2001 Nobel Prize in Economics. His most recent book Freefall: Free Markets and the Sinking of the Global Economy is available in French (Le Triomphe De La Cupidité, Liens Qui Liberent) and will be available shortly in 20 other languages, including Japanese, Spanish, German, and Italian.

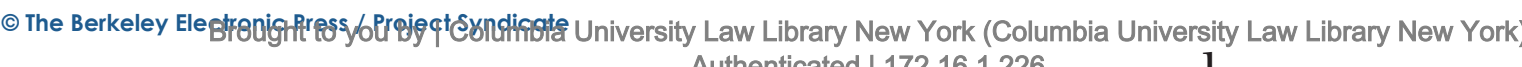

(whether for the public or private sector). One has to look not only at what a country or firm owes, but also at its assets. This should help answer those financial sector hawks who are raising alarms about government spending. After all, even deficit hawks acknowledge that we should be focusing not on today's deficit, but on the long-term national debt. Spending, especially on investments in education, technology, and infrastructure, can actually lead to lower long-term deficits. Banks' short-sightedness helped create the crisis; we cannot let government short-sightedness-prodded by the financial sector-prolong it.

Faster growth and returns on public investment yield higher tax revenues, and a five to six percent return is more than enough to offset temporary increases in the national debt. A social cost-benefit analysis (taking Download Date | 6/18/12 8:08 PM into account impacts other than on the budget) makes such expenditures, even when debt-financed, even more attractive.

Finally, most economists agree that, apart from these considerations, the appropriate size of a deficit depends in part on the state of the economy. A weaker economy calls for a larger deficit, and the appropriate size of the deficit in the face of a recession depends on the precise circumstances.

It is here that economists disagree. Forecasting is always difficult, but especially so in troubled times. What has happened is (fortunately) not an everyday occurrence; it would be foolish to look at past recoveries to predict this one.

In America, for instance, bad debt and foreclosures are at levels not seen for threequarters of a century; the decline in credit in 
2009 was the largest since 1942. Comparisons to the Great Depression are also deceptive, because the economy today is so different in so many ways. And nearly all so-called experts have proven highly fallible-witness the United States Federal Reserve's dismal forecasting record before the crisis.

Yet, even with large deficits, economic growth in the U.S. and Europe is anemic, and forecasts of private-sector growth suggest that in the absence of continued government support, there is risk of continued stagnation-of growth too weak to return unemployment to normal levels anytime soon.

The risks are asymmetric: if these forecasts are wrong, and there is a more robust recovery, then, of course, expenditures can be cut back and/or taxes increased. But if these forecasts are right, then a premature "exit" from deficit spending risks pushing the economy back into recession. This is one of the lessons we should have learned from America's experience in the Great Depression; it is also one of the lessons to emerge from Japan's experience in the late 1990's.

These points are particularly germane for the hardest-hit economies. The United
Kingdom, for example, has had a harder time than other countries for an obvious reason: it had a real-estate bubble (though of less consequence than in Spain), and finance, which was at the epicenter of the crisis, played a more important role in its economy than it does in other countries.

The U.K.'s weaker performance is not the result of worse policies; indeed, compared to the U.S., its bank bailouts and labor-market policies were, in many ways, far better. It avoided the massive waste of human resources associated with high unemployment in America, where almost one out of five people who would like a full-time job cannot find one.

As the global economy returns to growth, governments should, of course, have plans on the drawing board to raise taxes and cut expenditures. The right balance will inevitably be a subject of dispute. Principles like "it is better to tax bad things than good things" might suggest imposing environmental taxes.

The financial sector has imposed huge externalities on the rest of society. America's financial industry polluted the world with toxic mortgages, and, in line with the well established "polluter pays" principle, taxes should be imposed on it. Besides, well-designed taxes on the financial sector might help alleviate problems caused by excessive leverage and banks that are too big to fail. Taxes on speculative activity might encourage banks to focus greater attention on performing their key societal role of providing credit.

Over the longer term, most economists agree that governments, especially in advanced industrial countries with aging populations, should be concerned about the sustainability of their policies. But we must be wary of deficit fetishism. Deficits to finance wars or give-aways to the financial sector (as happened on a massive scale in the U.S.) lead to liabilities without corresponding assets, imposing a burden on future generations. But high-return public investments that more than pay for themselves can actually improve the well-being of future generations, and it would be doubly foolish to burden them with debts from unproductive spending and then cut back on productive investments.

These are questions for a later day-at least in many countries, prospects of a robust recovery are, at best, a year or two away. For 
now, the economics is clear: reducing government spending is a risk not worth taking.

Letters commenting on this piece or others may be submitted at submit.cgi? context=ev. 